\title{
Spiritual Activism. Saving Mother Earth in Sápmi
}

\author{
Siv Ellen Kraft
}

Department of Archaeology, History, Religious Studies and Theology, UiT The Arctic University of Norway, P.O. Box 6050, N-9037 Langnes Tromsø, Norway; siv.ellen.kraft@uit.no

Received: 10 June 2020; Accepted: 8 July 2020; Published: 9 July 2020

\begin{abstract}
Arctic Shaman Circle was founded in Oslo in November 2018. This article discusses what the Circle's founding document refers to as "spiritual activism", and how this was translated into action over the year that followed. I will follow one case in particular, which concerns plans for a power plant at the base of the mountain Aahkansnjurhtjie in the South Sámi area. Aahkansnjurhtjie is a sacred Sámi mountain, the shamans claim, and should be protected accordingly. My focus is on the learning processes that have emerged as the shamans have explored and argued the case, locally and nationally. I examine the negotiations that have happened along the way, in a political climate that has so far been hostile to religious arguments of any sorts, and in this example, involves a group that is contested among the Sámi. Finally, I look at the role of "indigeneity" in regard to claims, performances and responses to these particular concerns, as these have played out in different parts of the Sámi geography.
\end{abstract}

Keywords: Sápmi; Sámi shamanism; spiritual activism; indigenous religion(s)

\section{Introduction}

Indigenous people have a spiritual relationship to nature, which commits them to live in balance with Mother Earth. Shamanism is the designation of indigenous peoples' spirituality. The Arctic Shaman Circle promotes this perception of nature and society (Myrhaug et al. 2019) ${ }^{1}$

Arctic Shaman Circle ${ }^{2}$ is the most recent addition to shaman milieus in Norway. ${ }^{3}$ It is also the most explicitly indigenous shaman organization to have been established in Norway and Sápmi more broadly and the first that has foregrounded spiritual activism, and positioned societal development over personal development. Let me quote its objectives in full, up front:

(1) To help all Sami and other indigenous people in the north get back and develop their spiritual cultural heritage, according to U.N.'s human rights.

1 No.: Urfolk har et åndelig forhold til det naturen, noe som forplikter å leve i balanse med Moder Jord. Sjamanisme er betegnelsen for urfolks åndelighet. Arktisk Sjamansirkel fremmer denne natur samfunnsforståelsen. The quote is from a letter to the editor in the Sámi newspaper Ságat, by the council of Arctic Shaman Circle (Eirik Myrhaug, Erena Rhöse, Nadia Fenina and Hege Dalen), under the title "Aahkansnjurhtjie /Kjerringtind ett hellig fjell". See https://www.sagat.no/mening/ aahkansnjurhtjie-kjerringtind-ett-hellig-fjell/19.19440

2 Arktisk Sjamansirkel (Arctic Shaman Circle) was founded by Eirik Myrhaug, Erena Rhöse, Nadia Fenina and Hege Dalen and is currently led by a council (no.: råd) comprised by these same people. Myrhaug is a Sámi noaidi and elder (from Sápmi on the Norwegian side), Rhöse is a Maori water shaman (living in Sápmi on the Swedish side), Fenina is a Sámi noaidi (living in Sápmi on the Russian side), and Hege Dalen is from Hattfjelldal, and works as coordinator for the Circle. Myrhaug is head of the council.

3 A distinctively Sami shaman milieu emerged in Norway from the late 1990s. Having so far worked within the frames of Michael Harner's "Core Shamanism", Sámi shamans increasingly turned to the religion of their ancestors. This development has been explored elsewhere, most extensively by Trude Fonneland (2010, 2017). See also (Fonneland and Kraft 2013; Kraft 2009). 
(2) To increase knowledge of the connection between nature and cultural landscapes, work and indigenous people's spirituality.

(3) To make visible Sámi and other indigenous people's spiritual knowledge traditions.

(4) Make ethical rules for shamanistic practice accessible and accepted in society.

(5) The Arctic Shaman Circle shall create an environment in which the circle is the force.

(6) The Arctic Shaman Circle shall be a unifying network for all shamanistic workers.

(7) Develop a circle that includes Sápmi and other countries with indigenous peoples from Arctic regions: Russia, Japan, Alaska, Greenland, Island, Faroe Islands, Finland, Sweden, Denmark and Norway.

(8) Make shamanistic practice accepted as a profession.

(9) Help implement spiritual activism: actions for the support and development of indigenous people's spiritual connection to nature. ${ }^{4}$

In an attempt to shed light on unfolding developments at the intersection of religion, activism and indigeneity, this article deals with the first year and a half of Arctic Shaman Circle (2018-2020). I have been interested in the processes of indigenizing and religionizing, as the shamans have entered novel grounds, and negotiated a position for themselves vis-à-vis the complicated geographies of "Sámi religion" on the one hand and the largely secular spaces of Sámi (and Norwegian) activism on the other. My main case is the protection of Aahkansnjurhtjie, a mountain in the South Sámi area, referred to in the first annual report of the Arctic Shaman Circle as its "pilot case" (Arktisk Sjamansirkel 2019). I have followed the life of this case as it has been translated into action, in different contexts, on different scales and for different audiences, including a community meeting at the Sámi center in Hattfjelldal, a church in Oslo, news-media and online locations. The Facebook groups "Arktisk sjamansirkel" (Arctic Shaman Circle) and "Aahkansnjurhttjie: Kjerringtinden-beskytt hellige fjell" (protect sacred mountains) have enabled access to activities and communication along the way, for me and for the people involved, most of whom live spread across Norway and Sápmi. ${ }^{5}$

My methodological approach has been explorative and inductive, based on presence at the events discussed and long-term fieldwork in Sámi areas. The following themes have struck me as significant and will constitute my focus here. First is learning, as the shamans have explored the case, argued the cause and performed their claims, and with implications not only for religion-making on shaman terms but for the revitalization of traditions in Sápmi more broadly. Second is negotiations and diplomacy. The shamans are well aware of the challenges facing them, including the secular premises of activism, and the contested position of shamanism (particularly in the Sámi settlement areas).

Third is the role of "indigeneity" in regard to claims, performances and responses. My approach to this dimension has been shaped by a multi-year comparative project on indigenous religion(s), centered on the relationship between a globalizing discourse and local formations (Kraft et al. 2020; Johnson and Kraft 2017; Alles and Tafjord 2018). By "indigenous religion" I mean a flexible, but fairly standardized, vocabulary of assumed similarities: harmony with nature, healing and holism, antiquity and spirituality, shamanism and animism, along with material and practice-based registers (Kraft et al. 2020). Among my concerns are the ways- and means by which persons, acts and settings become recognizable as indigenous and religious, and the extent to which indigenous religion has become a resource (e.g., politically and in regard to religion-making). Attention to

4 The objectives were handed out and discussed at the founding meeting of the Arctic Shaman Circle in Oslo on 17 November 2018, and was later published on its Facebook group (also titled Arctic Shaman Circle). They have been translated by me from Norwegian.

5 I am not myself Sámi and do not speak Sámi languages, but have lived and worked in an area that is both Sámi and Norwegian since 2000 (in Tromsø, Northern Norway) and have conducted interviews and fieldwork in different parts of Sápmi on the Norwegian side over the past decade. The material gathered for this article is part of a larger project on contemporary religion and spirituality in Sápmi on the Norwegian side. Interviews have been based on the confirmed consent of the people in concern. Some of them have read and commented on drafts of this article. 
scales and translations is basic to this perspective, along with a focus on performance and display. My concern is not with truths, faults and authenticity. I am interested in what indigenous religion enables, makes possible, and brings into existence, who uses and opposes these registers, and why and with which results.

\section{Saving Aahkansnjurhtjie}

Hattfjelldal is a large, and sparsely populated municipality ${ }^{6}$ in the South Sámi area, bordering Sápmi on the Swedish side in the east. Just under 600 people live in the village by the same name. On 22 November 2018, approximately fifty of them-including shamans, local reindeer herders and representatives of the municipality board-gathered at Sijti Jarnge, the Sámi culture and develop-ment center. The Facebook invitation introduced the meeting as follows:

We invite to a dialogue on plans for development of a power plant in Stikkelvika, Hattfjelldal, with great consequences for Sámi nature, work and culture. Both the reindeer herders, Nordland county council, the Sámi Parliament and Friends of the Earth Norway have strongly opposed the plans, based on the consequences it will have. Only the muni-cipality is positive to the plans. [ ... Aahkansnjurhtjie $]^{7}$ is a landmark, an identity symbol for all of us who live around Røssvatn. It is also a sacred (no.: hellig) mountain, a mountain one turns to, to seek advice, knowledge and protection. Sacred mountains are among the most important tradition bearers in Sámi culture. U.N. human rights give indigenous people's sacred places a particular protection. Development on Tromsdalstinden ${ }^{8}$ was stopped during plans for Olympic Games in Tromsø for this reason. Come to Sijti Jarnge and meet representatives of Friends of the Earth Norway, reindeer herding and Sámi culture workers. ${ }^{9}$

Asked by me whether people in Deatnu (his homeland in Finnmark) would be ready for a meeting like this, the Sámi politician and activist Beaska Niillas answered yes, but that he had never attended anything along these lines anywhere in Sápmi. The organizers referred to the event as historic. This was unusual in at least three ways. First, sacred places have rarely been talked about publicly, due partly to what is commonly referred to as a Sámi culture of silence (concerning matters positioned outside of Lutheran orthodoxy) and a loss of knowledge about sacred landscapes in the past. Second, shamans and politicians have rarely gathered for discussions of any sort, and third, "the sacred" has so far been kept out of land-claims and legal contexts (Årsheim 2018).

The program was introduced by the two local women in charge of the initiative: Hege Dalen and Cecilia Persson. I knew Dalen from before as a board member of the Arctic Shaman Circle, and as the producer and coordinator of The Shaman Council of the Isogaisa festival, in Troms county. ${ }^{10}$ Persson is an actress, originally from Sápmi on the Swedish side, currently head of Åarjelhsaemien

6 A total of 1414 people were registered as living in Hattfjelldal municipality in 2018 (Aarborten tjielte, in South Sámi). For information about the village and the municipality, see http://www.hattfjelldal-kommune.no. Hattfjelldal municipality has since 2017, and as one of 11 municipalities, been a part of the management area (no.: forvaltningsområde) for Sámi languages. Inhabitants in these areas have the right to be served in Sámi when dealing with public offices, and they have increased rights to Sámi language training. The South Sámi language is on UNESCO's red list of seriously endangered languages. On the South Sámi, see also (Berg-Nordlie 2018).

7 A brief note on language usage. I will refer to names in Sámi for the settlement areas in inner Finnmark and for the mountain in Hattfjelldal, as well as for certain terms that are commonly used by members of Arctic Shaman Circle (whether the people in concern are Sámi and speak Sámi languages or not). For the Sámi name of the sacred mountain in Hattfjelldal (called Kjerringtind in Norwegian), I follow the spelling used by Norsk Kartverk (2020) (the Norwegian Mapping Authority): Aahkansnjurhtjie. The Facebook group "Aahkansnjurhttie: Kjerringtinden-beskytt hellige fjell" was set up with a different spelling, and will be referred to by me as such. Its organizers (Hege Dalen and Eirik Myrhaug) has later used "Aahkansnjurhtjie" primarily, but the name of the Facebook group has remained the same.

8 On the case concerning Tromsdalstinden, see (Kraft 2004, 2010).

9 Norwegian and Swedish were the languages used during the meeting, along with occasional usage of Sámi; mostly in the form of an opening sentence by speakers when presenting themselves, and through usage of select terms. All translations are from Norwegian or Swedish, and translated by me.

10 On the shaman festival Isogaisa, see (Fonneland 2017). 
Teatere (South Sámi Theatre), and the partner of Ole Henrik Kappfjell, a reindeer herder in the Jillen Jnaarke district. The program comprised ten presentations, lasted four hours, and ended with a drum ceremony by a group of local shamans. ${ }^{11}$ Erena Rhöse contributed in the form of three ceremonies: at the beginning, after a coffee-break and along with local shamans at the end.

Let me start with the two extremes of an otherwise mixed encounter, thereby to bring some of the complexities into relief. Starting out, the mayor (Harald Lie) expressed sympathy for local concerns. Having grown up on a goat farm in the south of Norway, he could relate to the strong reactions to the plans. Shifting from the informal style of fellow citizen to the formal register of political leadership, he then turned to a prepared manuscript that he read out loud. We learnt (at length) about energy needs, impact assessments, careful considerations, extensive information flow, and the board's decision as the inevitable conclusion to all of this. Their current task was to negotiate with the developer the mayor ended, thereby to secure maximum yield for people in Hattfjelldal.

Rhöse entered the circle in a Maori dress, with feathers in her hair, facial tattoos marking her identity and origin, and carrying two plastic containers with water and a small bundle of herbs. Dalen later told me that the water had been collected from Aahkansnjurhtjie, thereby to secure the mountain's presence during the meeting, as a "person" and main plaintiff. Rhöse was introduced as a traditional Maori, descending from a royal family. She presented herself through a Haka style ceremonial reply, addressed directly to the mayor, and one that shifted between soft appeals and strict demands. "I give you this", she started gently, offering the water and the herbs to the mayor: "is it ok? I don't want to scare you." Then, facing the audience, she told us to stand up for our human rights. As we failed to react, she repeated the command, now shouting: "Get up"! We did, including the mayor, now holding the bottle and the herbs. He looked uncomfortable, but performed the task assigned to him as Rhöse continued her speech, moving swiftly between appeals and demands, human rights language and mythological references. "I have done my assessment analysis" she concluded facing the mayor:

And I think 20 generations ahead. Will you pay your share? [ ... ] what will you do when there is no longer water to drink?

Then, switching to a more threatening register:

With Mother Earth waking up-you can stop a volcano. [ ... ] And this consequence has been experienced when one has tried to build on sacred places in New Zealand. It was a terrible situation, until they came and spoke to the local population. I don't want to scare you, but we are threatened by the world's climate. It's you and me now-twenty generations.

Finally, Rhöse thanked us and performed a last haka. A few of the Sámi hummed along. The mayor looked relieved.

This was a performance-based representation of the case, the cause and solutions. Rhöse performed her refusal of the mayor's arguments, and the regime that he spoke through and on behalf of; its facts, methods, morals and priorities. Contrasting bureaucratic procedures and anonymized decision making, was a personal encounter between herself and the mayor. Contrasting the destructive and shortsighted ways of Western capitalism was the strength, needs and wisdom of Mother Earth. The performance came forth as "indigenous" through Rhöse's design, presence and appearance (tattoos, feathers, herbs, haka movements), and as "indigenous religion" through invocations of Mother Earth, holism, animism,

11 A first session on "Consequences for reindeer herding" was cancelled, as the timing collided with the gathering of reindeer, a process that only the reindeer control. Next Persson spoke under the title "To live with sacred mountains," followed by Mayor Harald Lie on "Stikkelvika power plant-status." Beaska Niillas had been asked to describe "The landscape from a Sámi perspective," Thorbjørn Børgefjell shared "Experiences from the Aahka-mountains," Tom Kappfjell presented plans for a World Heritage application, Sigrid Stångberg from Vadtejen Saemiej Sijte spoke about "Atoklimpen culture reservation-a sacred cultural environment," and, finally, two talks by Erik Norberg (from Saemien Sijte) on the "protection of sacred landscapes," and Frode Solbakken (from Friends of the Earth Norway) on "Nature values around Kjerringtinden." 
and the sacred. As her on-stage collaborators, the shamans moved towards the indigenous and the traditional domain that they identify with, and away from the "new" and "neo" with which they have often been associated. Meanwhile, Rhöse's position as Maori avoided explicit references to local traditions (and tensions), yet linked them to a shared category of indigeneity. Her message moved between Maori and upscaled vocabularies of indigenous religion, and between concrete matters (this bottle of water) and existential concerns (water in general). Resemblance with the "Water is life-" slogan of the Standing Rock movement (2016-2017) must have been apparent to many among the audience. Standing Rock was covered extensively in Sámi and Norwegian news media; Beaska Niillas was one of the most profiled voices of solidarity actions in Sápmi and for Sámi actions at Standing Rock (Kraft 2020; Johnson and Kraft 2018). Here, like for Standing Rock, a local case was upscaled to the level of global concern. The mayor was held personally responsible for not only Aahkansnjurhtjie, but for the future of Mother Earth. This was a refusal in the sense suggested by the Mohawk scholar Audra Simpson (2014), and through the sacred as a language for ultimate claims.

Locals were divided on the proposed plan. This meeting gathered opponents mainly, with only the mayor and two other persons from the municipality board representing the supporters. "We are gathered here to try to understand a landscape used through thousands of years", Dalen said during her welcome. Parts of Sámi cosmology have never been talked about publicly, she added. She accordingly felt humbled by the steps taken by locals. Persson was first out. She started with her upbringing in a Christian family in Sápmi on the Swedish side. Her father had taught her how to behave respectfully in nature. During university studies, she had learnt more about these practices and what they mean. Among the things she learnt is that Sámi religion "is animistic;" that "nature is alive [ . . ] with its own soul." The plans for development constitute an assault from this perspective she concluded, and one that she feels responsible for confronting.

"The Sámi silence" is a complex term, denoting matters that are not talked about, or in private contexts only. It refers to collective rather than individual matters, and to inherited wounds from the past, as a result of missionary and forced assimilation, ${ }^{12}$ and the stigmatizing and even demonizing of Sámi traditions that they brought about. Silence has for religious matters been related to believes and practices from the pre-Christian past, existing outside of or intertwined with Lutheran Protestantism. I have heard it talked about in different ways, ranging from silence as loss (for instance with practices that have been passed on, but whose "meaning" is no longer known), to silence as secrecy (in the sense of consciously hidden from certain peoples or contexts). Persson invoked both forms. She talked about her own loss of knowledge, and about the strategic secrecy of others: "Sacred places become destroyed when they become known. People come there and litter, tag, disturb the place." Now, in the face of a larger threat, "it's time to act and speak up, and thus give other people a chance to understand," take action while there is still time. "I have taught myself to respect the Christian tradition", Persson ended: "I think such respect should be mutual."

The mayor steered clear of religious (and indigenous) registers, and said little during the discussion that followed. He was followed by Beaska Niillas, who had been invited to talk about "the landscape based on a Sámi perception of reality." Starting out, Niillas noted that there are many Sámi perceptions of nature. This would be his, based on his relationship to his landscapes, "up there" in Deatnu. Niillas spoke along lines that are basic to Sámi discourses on human-nature relationships: acting respectfully, asking for permission and striving not to leave traces. He talked in low-key ways about everyday life, but of duties and responsibilities of an ultimate kind, related to the protection of the land, and the life it enables. Colonialism was invoked through "agreements that mean zero" and through the ignorance of visitors from outside, presented as attacks on the we of his story, "my people" and the place itself. There were no explicit references to religion (or indigeneity) in his talk, but descriptions of relationships and responsibilities—to the land, and to ancestors-came close

12 The politics of forced assimilation is for Sápmi on the Norwegian side known as the "politics of Norwegianization". 
to notions of animism, holism and sacred claims. Niillas has used sacred claims elsewhere (Kraft 2020). They are commonplace among many of his indigenous allies (e.g., connected to the Standing Rock protests) as ways of articulating indigeneity and solidarity (Kraft 2020). "I travel constantly", he told me during our six hour bus-ride to Trondheim on the following day. As a full time politician and activist, Niillas belongs to an expanding group of indigenous cosmopolitans, many of whom are connected to each other and to international networks. Land conflicts are complicated. Locals face Kafka-ish bureaucracies, impenetrable legal systems, and dedicated lawyers. People such as Niillas know the system and how to maneuver it, and can accordingly offer advice, bridge scales, and release resources. ${ }^{13}$

The remaining speakers did use religious registers, in the titles of their talks and during presentations. Three of them referred to a recent lecture by the Sámi anthropologist Marit Myrvoll, centered on sacred mountains around the world. They had all learnt a lot, but mainly about the north Sámi area, which has been Myrvoll's primary concern. ${ }^{14}$ None of them knew much about Aahkansnjurhtjie. Nor did they know much about legal potential for protecting the sacred. The Friends of the Earth representative (Frode Solbakken) noted, based on Myrvoll's lecture, that he had kept thinking:

Why don't I know about this? Why doesn't the government know? Indigenous peoples are protected by a whole lot of laws. Politicians and NVE [The Norwegian Water Resources and Energy Directorate] should be pushed on these matters. Documentation should be provided, that this here is actually a sacred landscape. There may be cultural memories. Without critical attention, the process will move on.

Himself an outsider to Sámi traditions, Solbakken clearly assumed that a lack of information was connected to strategic secrecy on the part of locals. Like Persson, he found the causes of secrecy to be sensible, but no longer sustainable: "the only way to get at this [ ... ] is to document, to dare to say it. That's what I have to say. Now I look forward to collaboration."

I kept wondering whether the mostly silent audience agreed with the culture of silence claims. Such a culture was implied by many of the speakers, while speaking up-even screaming-was proposed, as in Rhöse's haka style call for a war on environmental destruction and the capitalist system responsible for it. The local shamans proceeded more carefully. Although obviously familiar with religious registers, the shamans have for the most part been silent in public contexts in the settlement areas. Places like Guovdageaidnu and Kárášjohka have not featured organized shaman activities at all, nor do any of the professional Sámi shamans live or offer their services there. Hattfjelldal does have a shaman milieu, ${ }^{15}$ but one that has for the most part stayed away from public settings. To come forth in this setting was a threshold. It was crossed carefully, with a drum session at the end as the most explicit statement. The shamans wore ordinary clothes, carried no ritual artefacts other than the drums (which were displayed and used during the last part only), and consistently resigned from framing the stage and claiming the topics. Being in charge of the meeting (with Persson), Dalen could have, but did not, include a shaman on the list of speakers, nor were specifically shaman issues raised. I cannot recall (or find in my notes) the word "shaman" used at all. Rhöse was introduced as a traditional Maori elder. Her performance was introduced as "ceremony", (no.: seremoni) a word used in both shaman and indigenous contexts and accordingly not marked clearly as one or the other. The shamans left the stage for others to come forth, and for local traditions to be prioritized. The rest

13 On indigenous forms of cosmopolitanism, see (Forte 2010).

14 Some of them also referred to publications on these matters by Myrvoll. See Myrvoll $(2017,2018)$

15 sked about the shaman milieu in Hattfjelldal and the surrounding area, Dalen answered that she used to meet regularly with a group of approximately 8 shamans in Hattfjelldal and Mosjøen. There are also shaman milieus at Dønna, at Drevja outside of Mosjøen, and in Korgen. None of them have entered Arctic Shaman Circle. Dalen says that they work with self-development; meditation, drum journeys, etc., "but do not want to get into the public" (no.: vil ikke inn $i$ det offentlige). 
of the audience kept their opinions about the shamans to themselves (if they had any), and did not problematize their presence.

\section{Documenting Sacredness, Building the Case}

Dalen co-organized the meeting at Sijti Jarnge, and spearheaded much of the work that followed. An open Facebook group was established ("Aahkansnjurhttjie: Kjerringtinden-protect sacred mountains"), followed by a (closed) work group comprising 11 members, myself included. ${ }^{16}$ A press release resulted in a full page interview with Dalen in the left-wing, Oslo-based newspaper Klassekampen (on 03.12. 2018). The local newspaper Helgelendingen printed short pieces related to the opposition, including a letter to the editor by a Sámi Parliament representative, but nothing about the meeting at Sijti Jarnge and the still small-scale protest. NRK Sápmi ${ }^{17}$ remained silent.

For legal action, a double approach was chosen, with two sets of complaints to NVE by Friends of the Earth Norway ${ }^{18}$ and locals, respectively, and with the latter aiming for the Cultural Heritage Act from 1978. A paragraph on Sámi cultural heritage is included in this act, ${ }^{19}$ covering "Sámi cultural heritage [ ... ] from 1917 and before", and including "cult places" (no.: kultsteder) and "other sites which archeological findings, tradition, faith, legend or custom are connected to." 20

Dalen kept the Facebook site alive through regular postings, comments and updates, ranging from relevant academic articles and newspaper clips to legal documents, mainly from Sápmi, increasingly from elsewhere in the indigenous world, and to a large extent focusing on protests, conflicts over land, environmental claims and climate change issues. Summaries from speeches at the November meeting have also been posted, along with comments on the planned complaint. A search for physical traces in the landscape was, for this complaint, ruled out, since the area is covered by snow during the winter, but Dalen interviewed some of the local reindeer herders and encouraged people to share stories through the Facebook group. Some did. Others volunteered to make maps, explore place names and look for symbolic and mythological references. The results were shared with locals in the form of a series of short articles in Helgelendingen, centered on the talks at the November meeting. During the fall of 2019, a short film was produced and circulated online, ${ }^{21}$ along with the petition "No to the development of Stikkelvika Powerplant and the regulation of Kjerringvatnet in Hattfjelldal Municipality, Nordland. Norway needs better protection against the development and destruction of sacred places in nature." 22

Dalen summarized their findings so far in a Facebook post on 13 August 2019:

Based on the rights stated in The law on cultural memories, the regulation plan of the municipality, The European Landscape convention, the ILO Convention 169, article 5, it is clear that development in sacred landscapes, such as the sacred mountains around Røssvatn and Kjerringtinden, is not a correct path forward. Several characteristics indicate that Aahkansnjurhtjie should be seen as a sacred mountain:

Language: "aahka, which means woman, the elder, grandmother. Aahka can also refer to the goddesses Saaraahka, Uksaahka and Juhksaahka. ${ }^{23}$

\footnotetext{
16 I have occasionally posted articles of relevance to the group, but have not participated in discussions.

17 NRK Sápmi is the Sámi Branch of the Norwegian Broadcasting system, located in Káráśjohka.

18 No.: Naturvernforbundet (Norway's largest environmental organization).

9 https://lovdata.no/dokument/NL/lov/1978-06-09-50

20 No.: Tingsteder, kultplasser, varp, brønner, kilder og andre steder som arkeologiske funn, tradisjon, tro, sagn eller skikk knytter seg til.

21 The film was made by Jessica Ullevålseter, Tinna Björk Ólafsdóttir and Molly Morberg. https://www.youtube.com/watch?v= XknwQvkf79k\&t=228s.

22 No.: Nei til utviklingen av Stikkelvika kraftverk og regulering av Kjerringvatnet $i$ Hattfjelldal kommune, i Nordland. Norge trenger bedre beskyttelse mot utvikling og ødeleggelse av hellige steder i naturen.

23 No.: aahka, betyr kvinne, elder, bestemor. Aahka kan også vise til guddinnene Saaraahka, Uksaahka and Juhksaahka. See also Myrvoll (2018).
} 
The mountain can be seen over the entire area of Røssvatn and is a landmark for people in inner Helgeland.

From the mountain you directly face other sacred mountains such as Hatten, Okstindan, Atoklimpen, Hatten and De syv søstre.

Aahkansnjurhtjie-Kjerringtinden has a special form.

A special sacrificial grave (no.: offergrav) has been found near the mountain summit.

For reindeer herding, the landscapes in which the reindeer dance is sacred.

This is the very heart of the Jillen Njaarke reindeer grazing area.

There is a particular respect for this mountain. For its power (no.: kraft), for the peace it invokes.

Galina Lindquist (1997) has noted of urban shamanism in Sweden that a few persons have been running much of the show. This has also been the case for the Arctic Shaman Circle. ${ }^{24}$ The majority of activities have been organized by Myrhaug and Dalen; Myrhaug for most of the events in Oslo, and Dalen for most of the work in Hattfjelldal (concerning Aahkansnjurhtjie) and for digital spaces (the Facebook groups). Myrhaug has activist experience from the Alta-protests during the late 1970s and early 1980s. As the front figure of shaman activism, he has combined information spread (through texts and interviews in news media) with participation in enviro-activist events, often in the form of four direction ceremonies. The annual report for 2019 refers to 11 public ceremonies conducted by Myrhaug, including the Climate festival in Oslo on January 5th (as an invited part of the program), and with mayor Marianne Borgen as a part of the ceremony. The report also covered Sámi national day celebrations in Oslo (6 February) in order to make shamanism "visible in the public space", a demonstration against a copper mine in Repparfjord (Oslo, 16 February), short speeches in front of the Norwegian Parliament during a demonstrations against windmill plants (Oslo, 8 September), and an art performance in Sagene Church (to be dealt with in more detail below).

Dalen has written complaints and newspaper appeals, talked with politicians and activists, and related to the bewildering world of legal rights and municipality bureaucracy. Initiatives on the national level include the Truth and Reconciliation Committee (established in 2018). ${ }^{25}$ She has met with the committee to call attention to the case in Hattfjelldal, and to push its members on the need for religion to be included among the themes of reconciliation. Continued silence speaks of continued trauma as she sees it, and thus the articulation of such experiences should, in accordance with her views, be encouraged.

This has been a process of learning for Dalen and Myrhaug, active members of the Arctic Shaman Circle and locals in Hattfjelldal. Among their key objects of exploration is the mountain itself and the traditions connected to it, as recorded in sources from the distant past, and narrated by locals at their initiative. Among the results is an increasing body of knowledge, assembled for a specific cause (that of saving a threatened landscape), but available for other means, such as the further anchoring of shamanism in ancestral traditions, and the revitalization of local practices (as described by Persson at Sijti Jarnge).

24 The Arctic Shaman Circle had 65 (paying) members in 2019. Small groups of active members have gathered for other events, including for online group meditation through a spin-off group on Facebook (179 members on 13 May) devoted to this particular concern (Arktisk Sjamansirkels Fellesmeditasjon), and centered on the strengthening of Mother Earth, or specific sites. The Facebook groups "Aahkansnjurhttjie: Kjerringtinden-beskytt hellige fjell" (protect sacred mountains) and "Arkstisk Sjamansirkel" (Arctic Shaman Circle) had 451 and 1097 members, respectively, in May 2020.

25 The committee will deliver a report in 2022. Its mandate is to examine the Norwegianization politics and wrongs inflicted upon Sámis, through a historical mapping of the Norwegian government's politics and consequences thereof, including continued implications, and to suggest measures that may contribute to reconciliation. Dalen met with the committee in October 2019, partly to "announce Aahkansnjurthjie as a sacred mountain as a case" (Arktisk Sjamansirkel 2019). During the meeting, the committee expressed an interest in being invited to meetings and to being kept updated. 
The culture of silence has been challenged through this process. The mountain has been religionized, in the sense of talked about in religious registers. And it has been indigenized in a scalar $^{26}$ sense of the term, as a specifically Sámi sacred mountain (on the local scale), and as an indigenous mountain (on the scale of indigenous religion). The former includes an exploration of the appeal and power of the sacred, an approach that has to a little extent been explored by activists in Sápmi on the Norwegian side. Exceptions include indigenizing from outside, through encounters and collaboration with indigenous people elsewhere. This was to some extent the case for the Alta-protests and to a considerable extent for the Standing Rock protests fifty years later (Kraft 2020). It has also been the case for Aahkansnjurttjie; through the presence of Rhöse; through invocations of sacred (indigenous) mountains elsewhere, through usage of the registers of indigenous religion (holism, animism, shamanism etc.) and through legal rights pertaining to indigenous peoples and sacred places. The reindeer herders are still silent, but have been exposed to these same processes. As a result, they-and people in Hattfjelldal more generally—know more about sacred traditions connected to Aahkansnjurhtjie, about sacred mountains in Sápmi, and about sacred mountains as typical of indigenous peoples. Some of them, and some of the active members of the Arctic Shaman Circle elsewhere, also know more about politics and activism, about building a case, and about the difficulties involved in documenting sacredness and realizing rights.

\section{Mother Earth as Lávou-Aahkansnjurhtjie in Oslo}

On All Saints Day 2019, the installation Sacrum labellum (sacred certificates) was set up at Sagene Church in Oslo. The idea was to extend what has traditionally been a day of mourning the dead to encompass Mother Earth and "the nature that we keep destroying." ${ }^{27}$ Mother Earth was materialized in the form of a Sami lávou (tent), with a pile of reindeer antlers on top. The artist Jessica Ullevålseter was in charge of the design. Members of the Arctic Shaman Circle contributed to the planning, and in the form of wooden sticks and reindeer antlers from Aahkansnjurhtjie. ${ }^{28}$ By bringing parts of the mountain to Oslo, they hoped to add attention to the case, along with features and tangibility to Mother Earth. In a comment to a draft I had sent to her, Dalen added that "Kjerringstinden- Aahkansnjurhtjie is a threatened sacred mountain, a symbol for all the sacred places in the world which are now threatened." The point of the event was "to mourn the nature that is gone and protect the nature that still is, each and all from their own perspectives." 29

As they entered the church, the visitors received a one-page program, centered on Mother Earth and on indigenous peoples "who have a long tradition for living in harmony with nature." In the meantime, some forty people had gathered back stage in the sacristy for last minute directives: shamans (some of them visibly Sámi through gákti (Sámi traditional clothing), representatives of environmental groups, a small group of transsexuals, and a few members of Cosmological Life-Faith and the Sufi group Inayati. All but Ullevålseter were equipped with wooden, handmade sticks, many of which were decorated. Two of the Sámi shamans carried drums: Myrhaug and Nadia Fenina. The rest of the drums had been left behind. To have several shamans using drums would make this seem like a ceremony, the priest had reasoned in a conversation with Myrhaug that same morning. ${ }^{30}$

The performance started with a scream-like song by a woman on the upper floor, representing Mother Earth perhaps. Next, the participants entered, one after the other, for a solemn walk around the nave. The sound of the steadfast knocking of sticks on the church floor merged with their echoes

26 On scales, scaling, and scalability, see (Kraft et al. 2020).

27 From https://www.facebook.com/events/1272953992877487/

28 More than 70 antlers were collected by Vivi Røreng and Stig Langfjell from Jillen-Njaarke reindeer district, Byrije reindeer district, and Tor Enok Larsen and Lifjell reindeer district (Arktisk Sjamansirkel 2019).

29 Messenger communication with Hege Dalen, 11 January 2020.

30 There has occasionally been yoik and (more rarely drums) in churches in Oslo over the past decade, but only in the context of Sámi Christian services. Both practices have been completely kept out of church spaces in the Sámi settlement areas. 
and with cries from above. As they reached the front of the church, the sticks were carefully immersed in the lávou construct, one by one, thus allowing for its gradual completion and increased solidity. The loudest and most colorful task was assigned to Rhöse, dressed in black, with a large headdress made by capercaillie feathers from Hattfjelldal, and a three-meter-long cape in Maori colors. As she reached the aisle, a powerful chant filled the room; even the clearly bored children behind me turned quiet and paid attention. Having reached the lávou, Rhöse draped her cape around its lower parts, and sang Ave Maria (again very loud), thereby (Dalen later told me) inviting Mother Earth to enter the space and join the event.

The next session was centered on Ullevålseter and the lávou. Ullevålseter was barefoot, dressed in black, with a hair-like veil covering half of her face, and holding a step-ladder. It was time for the completion of the lavvu, which consisted in the careful placement of the reindeer antlers between the connected sticks at the top. A woman in gákti handed them to her, one by one. Ullevålseter piled them slowly, for each and one uttering quietly "keep your name holy, mother ... earth."

Finally, there were short speeches by Myrhaug, Fenina, Rhöse and representatives of some of the other groups. Rhöse used animist registers, based on nature as family: "I am daughter of a river. And that makes me related to my river, just as the mountain Aahkansnjurhtjie is a part of the people." ${ }^{\prime 31}$ Myrhaug ended his speech with a recently written manifest, devoted to peaceful co-existence with Mother Earth, and again with Aahkansnjurhtjie as the focal case and symbol. Its first seven verses talk of Mother Earth. The final refers to Aahkansnjurhtjie. Collectively, they allow for a scalar translation from this mountain (our mother, on the level of Sámis), to Mother Earth (nature in general, and all of life's relations):

The mountain Aahkansnjurhtjie is sacred, for she is aahka, our dear mother. We will live in peace with Mother Earth. I/we will work to fulfill the Aahkansnjurhtjie-manifesto. ${ }^{24}$

The manifesto was left in the hall for people to sign, later circulated on Facebook, and was put on print in the left-wing newspaper Klassekampen during the following week.

I asked a few people what they had made of the event. Some of the shamans were deeply touched, both by the event, by what they interpreted as the priest's courage and openness, and by the historic sense of it all. Some perceived it as an opening in the closure between Christianity and shamanism. Others found moves towards reconciliation between the people involved and their respective pasts: Sámi ancestors and the non-Sámi ancestors of missionaries and state-governments. The priest said he was relieved that it was over. He particularly liked a storytelling event by a woman representing Extinction Rebellion, since it stated clearly what this was about as he saw it, climate change and environmental concerns. The shamans had been Ullevålseter's idea, which he in the end had agreed to, but clearly had concerns about.

This was many things at once and different things for different people: art, politics, activism, reconciliation and interfaith dialogue; deeply spiritual, devil worship (according to the conservative Christian newspaper Dagen, a few days later), and inspiring but absolutely not a ceremony (the priest). The priest and the shamans agreed on the position of drums as markers of religion and instigators of ceremony; the priest by forbidding it, the shamans by respecting the ban. Rhöse's haka-style chants were allowed. Although ceremonial in their Maori contexts, these sounds and moves are simply foreign from Norwegian church grounds. It is the near other that concern us, Jonathan Z. Smith has noted, that we worry about, compare ourselves to, and distance ourselves from (Smith 2004). The Maori are distant others from the perspective of Norwegian Church life and thinking, historically and geographically,

31 All speeches and textual material were in Norwegian.

24 The Arctic Shaman Circle had 65 (paying) members in 2019. Small groups of active members have gathered for other events, including for online group meditation through a spin-off group on Facebook (179 members on 13 May) devoted to this particular concern (Arktisk Sjamansirkels Fellesmeditasjon), and centered on the strengthening of Mother Earth, or specific sites. The Facebook groups "Aahkansnjurhttjie: Kjerringtinden-beskytt hellige fjell” (protect sacred mountains) and "Arkstisk Sjamansirkel" (Arctic Shaman Circle) had 451 and 1097 members, respectively, in May 2020. 
and are accordingly less problematic. The Sámi have historically been near and distant, friends and foes, mission field and fellow Christians.

I kept thinking of the meeting in Hattfjelldal as compared to this happening in Oslo, as Aahkansnjurhtjie had moved geographically, from a secular to a religious space, and from the transparent setting of village life to the more anonymous setting of a big city. Sámi-ness was the dominant frame at Sijti Jarnge. Indigeneity was invoked through Rhöse's performance and through references to indigenous people and cases elsewhere. Religion was low key (again with the exception of Rhöse). The sacred was talked about, but carefully and tentatively. Emphasis was on the past and on the reindeer herders, not on the shamans and their religion. In Oslo, the sacred was foregrounded. The shamans led the action as the voices of Mother Earth, and for an audience of strangers. Shamanism and indigeneity came forth as the same and indistinguishable. The audience had no means of demarcating between who were indigenous and who were not. Indigeneity was foregrounded upfront (through the invitation and the information sheet on arrival) and was displayed and performed then and there, during the events. ${ }^{33}$

\section{Reactions and Responses}

I have so far focused on activism from the perspective of the activists. Let me shift focus to reactions and responses, and let me do so by way of two examples, involving Sámi critics and non-Sámi supporters, respectively, and positioned as distant selves and near others. My first example is from Ekko, a daily current affairs program on NRK radio. ${ }^{34}$ On 25 November 2019, it was announced as follows: "The Sámi view on nature-our solution to saving the climate? Can the sacred mountains of the Sámi be the tool we need to preserve nature?"35 Four experts had been invited to shed light on this matter: a theologian (with expertise on sacred mountains), two lawyers (with expertise on the legal rights of nature), and Myrhaug, introduced as Sámi noaidi, a board member of the Arctic Shaman Circle and treated as a representative of indigenous peoples and knowledge systems. For the introduction, the host had chosen the fictitious scenario of drilling through the walls of Nidarosdomen, Norway's most venerable church. "Why not", he added; "We are already drilling in the sacred mountains of the Sámi." Myrhaug agreed with the comparison, then moved on to Aahkansnjurhtjie and Arctic Shaman Circle's struggles to protect it. Asked whether "the Sámi view of nature is the future", Adele Matheson Mestad, lawyer and director of Norway's Institution for Human rights, ${ }^{36}$ noted as interesting how eco-centric legislation in parts of the world is entering mainstream law "after dialogue and pressure from indigenous peoples." Lawyer Odd Harald Eidmo responded that it is "at least a very interesting idea, how this can contribute to change our views on nature."

My second example is from a discussion on the Facebook page of the Sami scholar and activist Mikkel Berg-Nordlie. It was initiated by Berg-Nordlie himself on 17 February 2019, in the wake of a demonstration in Oslo against a mining project in Repparfjord (Finnmark), which the Arctic Shaman Circle was involved in. Having been denied a request to be a part of the program, the shamans had nevertheless entered during the last part of it Berg-Nordlie wrote. Their ceremony thereby came forth as a planned part of the protest, and thus—as he saw it—challenged the unity of a diverse crowd:

33 Similar foregrounding of indigeneity characterized media coverage in the aftermath of the event. For instance, in the liberal Christian newspaper Vårt Land later that week, Ullevålseter noted that having been invited to create an installation to mourn nature on All Saints day, she had decided to "invite in indigenous people to my work, since they still listen to and communicate with nature"'" (Ullevålseter 2019).

34 "Ekko" is a daily current affairs program on NRK P2. NRK is an acronym for Norsk Rikskringkasting (Norwegian broadcasting).

35 No.: Samenes natursyn-vår klimaredning?-kan samenes hellige fjell vxre verktøyet vi trenger for å verne naturen?

36 No.: Norges institusjon for menneskerettigheter. 
a religious ceremony is not something the participants in a broad protest against dump-wasting in fjords can gather around. On the contrary, it divides them, and is accordingly a terribly bad way of ending a direct action. (Berg-Nordlie)

Eighty-one comments had been added by the following day. Some of them defended the shamans, but the majority agreed. The risk of media profiling of "misleading images" was referred to by several of the contributors. Among the spin-off topics was an event during a direct action in Tromsø that same week, described by one of the participants as "similar." The comparison was disputed by a person who had been there and interpreted it as an artistic performance: "This was a theater group, no home mission." 37

Mikkel Berg-Nordlie grew up in the north, with Sámi traditions, and currently lives in Oslo. He is thus a diaspora-Sámi, but not a member of the growing community of "new Sámi"—individuals" who did not grow up with Sámi culture and traditions but have chosen an identity that their parents or grandparents rejected. His critique echo concerns that I have heard repeatedly in the north, concerning contemporary shamanism as a New Age or a new religious movement (and thus dismissed from the category of "Sámi religion"). They also echo a widespread preference for secularism as the premise of politics and activism. Most noticeable for my concerns was the complete lack of indigenous registers, and the explicit rejection of religion as a resource. The shaman presence was deemed destructive in regard to the unity of protesters on the one hand, and in regard to messages to outside audiences on the other. To be represented in the media as "shaman-related" was not on the list of preferences for this group and was clearly perceived as damaging.

Contrasting the dismissal and avoidance of religion and indigeneity in this context, was their position as a premise for the Ekko-episode. Both the radio host and the guests took for granted the position of the Arctic Shaman Circle as (1) a Sámi movement, and (thus) (2) an indigenous religion, and (3) not only closely connected to nature and to Mother Earth, but her stewardess and potential saver. Taken together, they exemplify what Bjørn Ola Tafjord (2018) has referred to as "indigenizing in a romantic mode", in this case from outside, by (relatively) near others, and confirmed by an insider from the north (Myrhaug), living in diaspora in the south.

News media coverage can be related to a similar divide as that of my two examples. News media in the south has covered Arctic Shaman Circle on a regular basis, and usually in positive terms. News media in the north have tended to classify it as "new" or "neo" (Fonneland and Kraft 2013). NRK Sápmi has not covered the Arctic Shaman Circle at all. Ságat—-the main newspaper in Guovdageaidnu and Kárášjohka-has featured one article, in the form of a letter to the editor by leading members of the Shaman Arctic Circle themselves. ${ }^{38}$

The chances for shamanism to be accepted as an "indigenous religion" seem overall to depend on the distance from what is commonly referred to as the "core Sámi areas" (in inner Finnmark); the greater the distance, the better the chances, higher in Oslo than in Hattfjelldal, and at the lowest in Guovdageaidnu and Kárášjohka. Shamanism has re-emerged as "cultural heritage" in these areas, and in Sápmi more broadly (Kraft 2016), but is more or less absent in the format of "religion." Asked about this situation, the shamans I have spoken to have referred to a continued fear of shamanic powers, based on continued trauma from missionizing and a continued culture of silence. Friends and colleagues of mine in Guovdageaidnu relate the silence to a lack of interest. People are silent because they do not care, not because of fear.

37 No.: dette var en teatergruppe, ingen indremisjon. None of the shamans contributed to the debate. Myrhaug later told me his version, which was for the most part in agreement with Berg-Nordlie's outline, but with a positive take. Having been denied access they had decided to go ahead, claim a spot and challenge the tendency for spirituality to be ruled out.

38 The text is signed Myrhaug, Fenina, Rhöse and Dalen, and is titled "Sacred mountains are the spiritual cultural heritage of our ancestors, which we are here to manage in the best ways possible for future generations." It was printed in Sagat 14.11.2019 (no.: "Hellige fjell er våre forfedres åndelige kulturarv som vi er her for å forvalte på best mulig måte for framtidige generasjoner"). 
Oslo is the main area of activities for Sámi shamanism, and an area with a substantial and increasing population of Sámi. ${ }^{39}$ Many among these are "new Sámi." All of them are diaspora Sámi, living lives at a distance from Sámi homelands, and from Sámi traditions in the form of place-based community lives. Contrasting the culture of silence in the north is a culture of loss and distance in these contexts, in the form of access to the traditional territories, and (for the "new Sámi" in particular) to tradition-based knowledge.

For parts of these milieus, what Graham and Penny has referred to as the established order of identity may have shifted. Indigeneity is no one's primary identity, they claim in the introduction to Performing Indigeneity: Global Histories and Contemporary Experiences (Graham and Penny 2014). I agree for the Sámi settlement areas, but not necessarily for the "new Sámi" in diaspora-settings. The process of "becoming" Sámi and indigenous are in such contexts likely to take place simultaneously, or even in the reverse order, with indigeneity as the model through which Sámi-ness is approached and reclaimed,,$^{40}$ and shamanism as one of the resources for doing so.

\section{End Reflections}

"Tradition is constituted in and through moments of struggle", Greg Johnson has argued; traditions are defined by "the commitments they demand, the learning and speaking they inspire, and the shared resources they contest and draw upon" (Johnson 2008, pp. 247, 255). I have followed "moments" in this sense of the term, along the trajectories of a particular case and a particular group of Sámi. Now at the conclusion of this article, the following points strike me as significant. First is activism as a space in which to negotiate the position of shamanism vis-à-vis the category of indigenous religion on the one hand, and new religious movements on the other. "New" is rarely good and mostly bad in the context of religion. Old can be bad, but is mostly good, and then is indigenous religion, as a particular form of old. More than any other category of religion, this formation is currently linked to environmental concerns and the saving of Mother Earth, not only in religious milieus, but by institutions such as the U.N. In the words of Chandler and Reid: "Indigeneity has become a marker for imagining new modes of living and governing in our contemporary condition of climate crises and economic uncertainty" (Chandler and Reid 2019, p. 1). Shamanism has been and is still contested in regard to the categorizations of new-old, indigenous-western. The chances for it to be included in these new modes of environmental imaginings are still higher in the south and in city contexts than in the north and in settlement contexts, but they would seem to have increased for the latter, at least in certain contexts and for this particular case.

A second point involves activism as a space for learning. Saving Aahkansnjurhtjie came with incentives for exploring Sámi traditions, for locals to break the silence and share their knowledge, and thus for processes of revitalization and religion-making. It came with stages for new and old traditions to be performed and tested, and for new audiences, many of whom would be unfamiliar with indigenous vocabularies (as for the meeting in Hattfjelldal) or Sámi traditions (as for the happening in Sagene Church).

Indigenous religion has offered resources in the form of scripts for activism, in the form of recognizable registers and authoritative designs, and as a translational device for the up-scaling of Sámi traditions. The goddess Máttaráhkká would have made little sense to audiences at Sagene Church. She made sense as Mother Earth, and in ways that matter to contemporary audiences. Máttaráhkká was the mother of specific daughters (the goddesses Sáráhkká, Juoksáhkká and Uksáhkká) and was related to pregnancy and birth. Mother Earth speaks of global connections, of the world as such,

39 NRK Sápmi on 21 October 2019 referred to a "Sameboom" in the cities. By 2019, Tromsø has become the largest Sámi municipality (with 1551 listed voters), above Guovdageaidnu (1520), Alta (1441), Káráśjohka (1351) and Oslo (949) (Idivuoma and Paulsen 2019). For studies of city Sámi and "new Sámi" (no.: nysamer), and the issue of how to be Sámi in the contemporary world, see Pedersen and Nyseth (2013), and Niittyvuopio (2020).

40 Rakel-Maria Niittyvuopio (2020) in her master-thesis explores one such example, through the Sámi artist Katarina Skår Lisa. 
and of premises for life. Máttaráhkká lived prior to environmental concerns and global imaginaries. Máttaráhkká as Mother Earth speaks of threats on this global scale and of how to solve them.

Funding: The publication charges for this article have been funded by a grant from the publication fund of UiT The Arctic University of Norway.

Conflicts of Interest: The author declare no conflict of interest.

\section{References}

Årsheim, Helge. 2018. Including and Excluding Indigenous Religion through Law. Numen 65: 531-61. [CrossRef] Alles, Gregory D., and Bjørn Ola Tafjord. 2018. Special issue, Performances and Mediations of Indigenous Religion(s). Numen: International Review for the History of Religions 65: 5-6.

Arktisk Sjamansirkel. 2019. Årsrapport 2019, unpublished document.

Berg-Nordlie, Mikkel. 2018. Sør-samer. Available online: https://snl.no/s\T1 \orsamer (accessed on 1 March 2020).

Berg-Nordlie, Mikkel. Berg-Nordlie's Homepage on Facebook. Available online: https://www.facebook.com/ misha.berg (accessed on 17 February 2019).

Chandler, David, and Julian Reid. 2019. Becoming Indigenous. Governing Imaginaries in the Anthropocene. London and New York: Rowman \& Littlefield.

Fonneland, Trude, and Siv Ellen Kraft. 2013. New Age, Sami Shamanism and Indigenous Spirituality. In New Age Spirituality: Rethinking Religion. Edited by Steven J. Sutcliffe and Ingvild Sælid Gilhus. Durham: Acumen Publishing, pp. 132-45.

Fonneland, Trude. 2010. Samisk Nysjamanisme: I Dialog med (for) Tid og Stad. Ein Kulturanalytisk Studie av Nysjamanar sine Erfaringsforteljingar- Identitetsforhandlingar og Verdiskaping. Ph.D. thesis, University of Bergen, Bergen, Norway.

Fonneland, Trude. 2017. Contemporary Shamanisms in Norway. Religion, Entrepreneurships and Politics. Oxford: Oxford University Press.

Forte, Maximilian C. 2010. Indigenous Cosmopolitans. Transnational and Transcultural Indigeneity in the Twenty-First Century. New York: PETER LANG.

Graham, Laura R., and Glenn Penny. 2014. Performing Indigeneity: Emergent Identity, Self-determination, and Sovereignty. In Performing Indigeneity: Global Histories and Contemporary Experiences. Edited by Laura R. Graham and Glenn Penny Lincoln: University of Nebraska Press, pp. 1-31.

Idivuoma, Mariela, and Simon Piera Paulsen. 2019. Sameboom" i Byene-Over 80 Prosent Økning", NRK Sápmi 21. October. Available online: https://www.nrk.no/sapmi/_sameboom_-i-byene-_-over-80-prosent-okning-1. 14737608?fbclid=IwAR0hYTrYkCNFQAHBjvKcc2eFWiaE_JidST63VurndQ1Qj5byr8fn4UAda9c (accessed on 18 February 2020).

Johnson, Greg, and Siv Ellen Kraft, eds. 2017. Brill Handbook of Indigenous Religion(s). Leiden: Brill.

Johnson, Greg, and Siv Ellen Kraft. 2018. Standing Rock Religion(s): Ceremonies, Social Media, and Music Videos. Numen 65: 499-530. [CrossRef]

Johnson, Greg. 2008. Authenticity, Invention, Articulation: Theorizing Contemporary Hawaiian Traditions from the Outside. Method \& Theory in the Study of Religion 20: 243-58.

Kartverk, Norsk. 2020. Aahkansnjurhtjie. Available online: https://www.norgeskart.no/\#!?project=norgeskart\& layers $=1002 \&$ zoom $=11 \&$ lat $=7294289.93 \& l o n=448378.19 \&$ markerLat $=7294289.927204336 \&$ markerLon $=$ 448378.187750396\&panel=searchOptionsPanel\&sok=Aahkansnjurhtjie (accessed on 10 June 2020).

Kraft, Siv Ellen. 2004. Et Hellig Fjell blir til. Om Samer, OL og Arktisk Magi. Nytt Norsk Tidsskrift 21: 237-49.

Kraft, Siv Ellen. 2009. Kristendom, Sjamanisme og Urfolksspiritualitet i Norsk Sápmi. Chaos 51: 29-52.

Kraft, Siv Ellen. 2010. The Making of a Sacred Mountain. Meanings of "Nature" and "Sacredness" in Sápmi and Northern Norway. Religion. An International Journal 40: 53-61. [CrossRef]

Kraft, Siv Ellen. 2016. Kulturarvifisering av Ritualer. Sjamanisme i Norsk Sápmi. Chaos. Skandinavisk Tidsskrift for Religionshistoriske Studier 65: 53-74.

Kraft, Siv Ellen. 2020. Indigenous religion(s)-in the making and on the move: Sámi activism from Alta to Standing Rock. In Indigenous Religion(s). Local Grounds, Global Networks. Edited by Siv Ellen Kraft, Bjørn Ola Tafjord, Arkotong Longkumer, Gregory D. Alles and Greg Johnson. London and New York: Routledge, pp. 59-88. 
Kraft, Siv Ellen, Bjørn Ola Tafjord, Arkotong Longkumer, Gregory D. Alles, and Greg Johnson. 2020. Introduction. In Indigenous Religion(s). Local Grounds, Global Networks. Edited by Siv Ellen Kraft, Bjørn Ola Tafjord, Arkotong Longkumer, Gregory D. Alles and Greg Johnson. London and New York: Routledge, pp. 1-20.

Lindquist, Galina. 1997. Shamanic Performances on the Urban Scene: Neo-Shamanism inn Contemporary Sweden. Stockholm: Stockholm Studies in Social Anthropology.

Myrhaug, Eirik, Nadia Fenina, Erena Rhöse, and Hege Dalen. 2019. Aahkansnjurhtjie/Kjerringtind ett hellig fjell. Sagat. Available online: https://www.sagat.no/mening/aahkansnjurhtjie-kjerringtind-ett-hellig-fjell/19.19440 (accessed on 14 November 2019).

Myrvoll, Marit. 2017. Gosa Bássi Várit Leat Jávkan? Where Have All The Sacred Mountains Gone. In Experiencing and Protecting Sacred Natural Sites of Sámi and other Indigenous Peoples. The Sacred Arctic. Edited by Leena Heinämäki and Thora Martina Herrmann. Cham: Springer International Publishing, pp. 101-16.

Myrvoll, Marit. 2018. Ålmåj, Áhkká ja Niejdda/Mannen, Kvinna og Jenta Sámij Bassetjåhkå/Samenes Hellige Fjell. Din. Tidsskrift for Religion og Kultur 2: 112-20.

Niittyvuopio, Rakel-Maria. 2020. «Gift of Stone» Artikulasjoner av Religion og Indigenitet: En Kunstners Utforskning av sin Samiske Identitet. Master's thesis, The Arctic University of Norway, Tromsø, Norway.

Pedersen, Paul, and Torill Nyseth. 2013. Bysamer og Bysamiske Institusjoner i Tromsø—et Nytt Trekk i Byens Historie. Ottar 295: 49-55.

Simpson, Audra. 2014. Mohawk Interruptus. Political Life Across the Borders of Settler States. Durham and London: Duke University Press.

Smith, Jonathan Z. 2004. Relating Religion: Essays in the Study of Religion. Chicago: University of Chicago Press.

Tafjord, Bjørn Ola. 2018. Modes of Indigenizing: Remarks on Indigenous Religion as a Method. International Journal for the Study of New Religions 9: 303-27. [CrossRef]

Ullevålseter, Jessica. 2019. Fornektelse av naturen er fornektelse av Guds kraft. Vårt Land. November 7. Available online: http://www.verdidebatt.no/innlegg/11753195-fornektelse-av-naturen-er-fornektelse-avguds-kraft (accessed on 12 December 2019).

(C) 2020 by the author. Licensee MDPI, Basel, Switzerland. This article is an open access article distributed under the terms and conditions of the Creative Commons Attribution (CC BY) license (http://creativecommons.org/licenses/by/4.0/). 